\title{
Annales Penceresinden Yemeğin Kültürel Tarihi: Ekmek ve Bira Örneği
}

\author{
Ayşenur Yilmaz ${ }^{\mathrm{ab}}$, Rüya Tellic
}

\section{Özet}

Yirminci yüzyıl tarihyazımında önemli bir yeri olan Annales okulu, geleneksel tarih yazımından farklı olarak ekonomik toplumsal ve kültürel tarihle de ilgilenir. Gündelik hayatın içerisinde tarih dışı görülen yemek, ekonomik ve sosyal süreçleri etkilemesi bakımından Annales'in çalışma kapsamına girer. $\mathrm{Bu}$ çalışmada, ekmek ve biranın antik dönemden üretim ve tüketim bağlamının değiştiği kapitalizme geçiş dönemine kadar uzun erimli bir sürecin ekonomik ve kültürel olarak değişimi temelinde farklılaşmalarının izi sürülecektir. Ekmek ve bira antik dönemden günümüze değin var olagelmiş iki temel tüketim maddesidir. Neolitik dönemle birlikte insanlığın beslenme rejiminde yerini alan ve tarih sahnesinden düşmeyen ekmek ve biranın, aynı hammaddeye dayandığı halde algılanma biçiminin nasıl farklılaştığı sorusu çalışmanın çıkış noktasını oluşturur.
Anahtar Kelimeler

Annales Okulu

Kültür Tarihi

Ekmek

Bira

Makale Hakkında

Geliş Tarihi: 01.03.2021

Kabul Tarihi: 21.06.2021

Doi: $10.18026 /$ cbayarsos. 888605

\section{Cultural History of Food the Annales Perspective: The Example of Bread and Beer}

\begin{abstract}
The Annales school, which has an important place in Twentieth-Century historiography, deals mainly with economic, social and cultural history. Food, which is seen as a non-historical subject in everyday life, falls within the scope of Annalesin's work in terms of affecting economic and social processes. The study will trace the differentiation of bread and beer on the basis of the economic and cultural change of a long-term process from antiquity to the transition period to capitalism, where the context of production and consumption changes. The question of how bread and beer, which took its place in the feeding regime of humanity with the Neolithic period and did not fall off the stage of history, differed in the way it was perceived, even though it was based on the same raw material, forms the starting point of the study.
\end{abstract}

Keywords

Annales School

Cultural History

Bread

Beer

\begin{tabular}{r} 
About Article \\
\hline Received: 01.03.2021 \\
Accepted: 21.06.2021
\end{tabular}

Doi: $10.18026 /$ cbayarsos. 888605

\footnotetext{
a ylmzaysenur001@gmail.com

b Doktor adayı, İstanbul Üniversitesi, Siyasal Bilimler Fakültesi, Siyaset Bilimi ve Uluslararası İlişkiler, ORCID: 0000-00030360-9156

c Doktor adayı, İstanbul Üniversitesi, Siyasal Bilimler Fakültesi, Siyaset Bilimi ve Uluslararası İlişkiler, ORCID: 0000-00024576-0842
} 


\section{Giriş}

Aydınlanma döneminin geleneksel tarih anlayışına getirdiği eleştirilerle birlikte tarihe farklı açılardan bakılması gerekliliği dile getirilmeye başlanmıştır. Geleneksel tarihyazımınında tarihin savaşlar ve siyasetle sınırlandırılmasına karşın insanın ve toplumun ilerlemesinde tarihin önemli bir rolü olduğunu vurgulayan Aydınlanma düşünürleri güzel sanatlar, hukuk, görenek, değer yargılarının gelişim süreçleri ve toplumsal tarih incelemelerine de yönelmişlerdir (Sönmez, 2008, s. 10). Auguste Comte'un öncülüğünü üstlendiği pozitivizmin tarih disiplininde etkili olmaya başlamasıyla birlikte tarihyazımının önceki yüzyıllara göre farklılaşma ve bilimselleşme eğilimi hızlanmıştır. Bu doğrultuda tarihyazımında en köklü değişim on dokuzuncu yüzyılda, Rankeci Devrim olarak adlandırılan bilimsel tarih anlayışına geçişle yaşanmıştır.

Leopold von Ranke profesyonel tarih yazıcılığını başlatan isimdir. Ona göre tarih, uzmanlar tarafından yazılması gereken bir bilimdir (Iggers, 2000, s. 25). Tarihin rivayet ve edebiyattan uzaklaştırılarak uzmanlar tarafından yazılması, bilimselleştirilmesi açısından önemli bir adımdır. Ranke'nin tarihin ana aktörleri olarak devletleri ele alması, tarihyazımını siyasi tarihle eş görülmesiyle sonuçlanır. Rankeci tarihyazımında devlet liderleri, büyük komutanlar, öncül isimler başka bir deyişle "büyük isimler" yer alırken sıradan insan ve ona dair konular kapsam dışında kalır. Tarafsızlık ve değerlerden arınmış bir tarih anlayışı savunan Ranke yukarıdan aşağıya bir tarih yazma yaklaşımını benimsemektedir. Ona göre tarihçinin tarafsız olarak gerçekte ne olduğunu anlaması için de yazılı kaynakları titizlikle incelemesi gerekmektedir.

Rankeci tarihyazımınında siyasi tarih merkezi bir yere sahipken ekonomik, kültürel ve toplumsal tarihin ikinci plana atılması, disiplinler arası iş birliğinin göz ardı edilmesi ve "küçük" insanların veya onların gündelik yaşamlarının yer almadığı eleştirisi yirminci yüzyılda gelişen tarih yazım yöntemlerinin temel çıkış noktasını oluşturmaktadır. Yirminci yüzyılla birlikte toplumsal yapılara ve toplumsal değişim süreçlerine dikkat çeken bir tarih anlayışına geçilmiştir (Iggers, 2000, s. 3). Bu yeni anlayışa göre tarihyazımı daha geniş bir nüfusu kapsar. Yirminci yüzyıl siyaset dışı konuların ön planda olmasının yanı sıra gündelik hayatın sıradan olarak değerlendirilen konularının da tarihyazımında yoğunlukla yer almaya başladığı dönemdir. Bu dönemle birlikte değişik ekoller tarihyazımında farklı yöntem ve yaklaşımlar geliştirir. Marksist tarihyazımı çoğunlukla ekonomiye ve iktisat tarihine odaklanırken, Annales ekonominin yanı sıra topluma ve kültüre odaklanır.

Bir dergi çatısı altında bir araya gelen Annales yazarları, çeşitli bilim dallarının işbirliğine önem verir ve çok disiplinliliği temel kabul eder. Bununla birlikte "büyük" adamların tarihi yerine "küçük, sıradan" insanların hayatlarını inceleme alanı olarak görür. Başka bir deyişle, Annales geleneği içerisinde siyasi tarihten daha çok insanların günlük yaşamını ilgilendiren konular ilgi görür. Olay odaklı tarihyazımı yerine, sorun odaklı tarihyazımı tercih edilir. Sorun odaklı yaklaşım kültür, uygarlık, medeniyet gibi kavramların incelenmesini beraberinde getirir. Annales Okulu tarihçiliği kültüre verdikleri önemle, kendinden önceki tarihçilik anlayışından farklılaşır. Dergi çeşitli konu ve alanlarda yayın yaparken Goody'nin (2013, s. 54) ifade ettiği üzere yemek ve yemeğin kültürel tarihi hakkında çalışmalara da yer verilir. Bu çalışmaları yapanların en başında ise Braudel gelmektedir. Watts $(2012$, s. 17) Annales Okulu'nun "neden yemek çalışılıyor?" sorusuna verdiği üç cevapla Annales kültür tarihçiliği ve yemek arasındaki bağı gösterir. Bunlardan ilki, ekonomik ve sosyal yapıların ayrılmaz bir parçası olması bakımından yemeğin gündelik hayat tarihi içerisinde önemli bir yere sahip 
olmasıdır. İkincisi, en eski uygarlıklardan beri gıdanın korunması ve gıda güvenliğinin devlet adamları ve hane reislerinin yakından ilgilendiği konular olmasıdır. Üçüncü ve sonuncusu ise yemek ve mutfak üzerine yapılan çalışmaların medeniyet olarak neye değer verildiğini göstermesi ve kişilerin veya toplumların kim olduğu hakkında bilgi vermesi açısından önemli olmasidir.

İnsanlığın temel ihtiyaçlarından beslenme eylemi, fiziksel bir ihtiyacın ötesinde sosyal ve kültürel önem taşır. Dünya tarihi içinde besinlerin sosyal, dinsel ve ekonomik yaşam içindeki yeri yüzyıllar boyunca değişikliğe uğramıştır. Buradan hareketle, makalede, ekmek ve biranın tarihsel süreklilik ve kopuş bağlamında farklı coğrafi mekânlardaki görünümleri kültür tarihi içinde değerlendirilmektedir. Neolitik dönemle birlikte insanlığın beslenme rejiminde yerini alan ve tarih sahnesinden hiç düşmeyen ekmek ve biranın, aynı hammaddeye dayandı $\breve{1} 1$ halde algılanma biçiminin nasıl farklılaştığı sorusu çalışmanın çıkış noktasıdır. Bu bağlamda makalenin ilk kısmında, Annales okulunun tarihyazımına kattığ yenilikler ve kültür tarihine verdikleri önem detaylandırılmaktadır: Annales Okulu'nun gelişimi, kurucu isimlerin okula katkıları ve ikinci dönemin başat ismi Fernand Braudel'in okul açısından önemi incelenecektir. İkinci kısımda, kültür kavramı üzerinde durulduktan sonra Braudel'in zamansallıklar olarak ele aldığ boyunca gerçekleştiği uzun erimli bir süreç olarak yemeğin kültürel tarihi çerçevesinde ekmek ve biranın serüveni değerlendirilmektedir. Sonuç olarak, ekmek ve bira örneklerinin farklı mekanlardaki kültürel karşılığının ekonomik yapı ve tarihsel bağlamla ilişkili olarak değişim gösterdiği savunulacaktır.

\section{Yöntem olarak Annales Okulu}

Annales 15 Ocak 1929'da Marc Bloch ve Lucian Febvre kuruculuğunda yayın hayatına başlamıştır. Annales bir okul olarak değerlendirilse de bir dergi etrafında birleşen entelektüellerin çalışmaları ve bu çalışmaların temel çizgisi üzerinden şekillenen bir oluşumdur. Kurucu isimlerin etkisi altında geçen ilk dönemin ardından 1945'ten sonra derginin kurumsallaşma süreci hızlanmış, 1956-1985 yıllarını kapsayan ikinci dönemi ise Braudel öncülüğüyle yayın hayatına devam etmiştir. Braudel sonrası dönemi ise derginin üçüncü dönemi olarak adlandırmak mümkündür. Dergi, yayın sürecinin başından günümüze kadar farklı dönemlerde farklı konulara ağırlık vermiş ve dönemsel farklılaşmalar yaşamış olsa da derginin temel çizgisinin, fikirlerinin değişmediği ve kuruluştan günümüze devamlılık gösterdiği iddia edilebilir.

Peter Burke (2014, s. 22), Annales'in arka planını oluşturan temel fikirlerin üç özelliğini vurgular. Bunlardan ilki sorun odaklı analitik tarihe odaklanılmasıdır. İkincisi, insan faaliyetlerinin tamamına eğilen bir tarih anlayışının gelişmesidir. Son olarak ise çok disiplinli çalışmaların yapılması ve disiplinler arası işbirliğinin önemsenmesidir. Burke'nin işaret ettiği özellikler; Annales'in olay odaklı, devlet merkezli ve tek bir disiplinin konu ve yöntemsel sınırları içerisinde gelişen tarihyazımından farklılığının altını çizer. Sorun odaklı yaklaşımın benimsenmesi kültürün, yapıların ve gündelik hayata dahil olan konuların ekonomik ve toplumsal kökenlerini incelemek açısından önemlidir. İnsan merkezli olması "sıradan" olarak adlandırılan konuların tarihin kapsamına girmesini sağlayarak, devlet merkezlilikten uzak biçimde tarihsel bilgi edinmenin imkanını sunmaktadır. Aynı şekilde insan eylemlerinin tamamı inceleme kapsamına alınırken, geleneksel tarihyazımının görmezden geldiği konuları inceleyerek "büyük" olayların kökenlerinin anlaşılmasına fırsat sunmaktadır. Derginin bir diğer özelliği olan çok disiplinlilik, derginin ilk editör kurulunda kendini göstermektedir: 
Modern ve eski çağ tarihçilerinin yanı sıra, bir coğrafyacı, bir sosyolog, bir ekonomist ve bir siyaset bilimci yer alırken bu durum kuruluş amacı olan ekonomik ve toplumsal tarih incelemelerinin derginin hâkim çalışma konusu olacağını gösterir. Çok disiplinlilik aynı zamanda karşılaştırmalı yöntemin benimsenmesini kolaylaştırdığ1 gibi toplumun bir bütün olarak ele alınmasını sağlar. Iggers (2000, s. 64), Annales' in çok disiplinli çalışmalar yapmasını önemseyerek Batı merkezci olmadıkları ve modernleşme kuramına bağlı kalmadıklarını iddia etmektedir. Ve son olarak Braudel'in yoğun bir şekilde savunduğu uzun erimli süreçlerin analizi, derginin tercih ettiği bir diğer çalışma şeklidir.

Burke (2014, s. 60), Bloch ve Febvre'nin yöneticiliğinde Annales'in yayın hayatına heretik bir çizgide başladığını ve bu dönemde "bir heretik olmanın gerekliliğine" sürekli vurgu yapıldığını ancak 1945 sonrası bu çizginin korunamadığını ve derginin Ortodokslaştığını söyler. Bahsettiği Ortodokslaşmadan kastının Braudel'le birlikte derginin kurumsallaşması ve daha belirgin bir yapıya bürünmesi olduğu iddia edilebilir. İkinci kuşağın önemli isimlerinden Georges Duby (1991, s. 204) ise derginin bütünsel tarihsel çizgisini kitlesel bir tarihten uzaklaştırarak derinlemesine sondaj şeklinde bir tarihçilik yapıldığına vurgu yaparak, çok uzun süreçlerin içine dalıp ve en dipteki konulara, temellere ve tabakalara önem veren bir tarih anlayışına sahip olunduğunu söyler. Duby'nin aynı yazının içerisindeki “...artık hiçbir şeyin değişmiyora benzediği en dipteki derinliklere kadar macera arayan..." şeklindeki yaklaşımı, Annales'in toplumsal yapılara ve kültürel meselelere olan ilgisini göstermesi açısından önemlidir. Bu yaklaşım sayesinde yapılar, insan, çevre, düşünce, inanç, kültür gibi konular tarih araştırmalarının kapsamına dahil edilmiş ve açıklama esaslı bir yaklaşım geliştirilmiştir. Özetlemek gerekirse, Annales klasik tarih anlayışından yeni bir tarih anlayışına geçerken açıklayıcı analitik bir yaklaşım ve birleştirici sentetik bir eğilime sahiptir (Yild1z, 1994, s. 38).

Annales'in kurucu isimleri veya yazarlarında bir tektiplik söz konusu değildir. Annales kurucuları bir tarih yazım kuramı formüle etmemiş, derginin amacını bir forum oluşturmak olarak lanse etmişlerdir. Yukarıda da belirtildiği gibi kurumsallaşma ve belirli bir yöntem ile kuramı takip etme Braudel'den sonra gelişmeye başlamıştır. Kurucu isimlerin genel çizgisi takip edildiğinde araştırmaların tarih boyunca bir değişim sürecini aktarmaktan çok, tarihin akışından ayırdıkları bir kültür ya da çağa odaklandıkları (Iggers, 2000, s. 57) ve bu konuları benzer yöntemlerle inceledikleri görülmektedir. Örneğin Febvre yoğunluklu olarak zihniyetler tarihiyle ilgilenirken Bloch ekonomi tarihine daha yatkındır. Her ikisi de sosyal bilimcilerin öncelikle çağdaş sorunlarla ilgilendiklerini belirtmekle birlikte, tarihçilerin kaynaklarına hangi sorularla yaklaşacaklarını ancak toplumsal bilginin diğer alanlarıyla uğraşan meslektaşlarının yardımlarıyla kavrayabileceklerini savunurlar (Tosh, 2019, s. 123).

Fevbre, sorun odaklı tarih, duyarlılık tarihi, düşünce tarihi, beşerî coğrafya vb. konuları tercih etmekle birlikte diğer tarihçilere de disiplinler arası çalışmalar yapmaları yönünde çağrı yapar (Burke, 2014, s. 54). Ayrıca özgül bir coğrafi, kültürel bölgedeki toplumsal, ekonomik ve siyasal yapılar ile düşünce ve davranış kalıpları arasındaki sıkı bağlarla ilgilenir (Iggers, 2000, s. 52). Bu ilgisinin doğal sonucu olarak disiplinler arası bölünmelere karşı çıkar. Ona göre tarihçiler gerekirse coğrafyacı, hukukçu, sosyolog ve psikolog olabilmelidir (Burke, 1985, s. 12). Böylece Fevbre ve onun öncüleri sayesinde daha önce tarihin temel konusu olarak kabul edilmiş konular merkezde olmak yerine toplumsal kültürün bir parçası olarak görülmeye başlanmıştır. Aynı zamanda kültür konusu da daha geniş çerçeveler tarafından incelenir hale gelirken estetik ve entelektüel bir konu olmaktan çıkarak halkın yaşamını sürdürme tarzı 
olarak kabul edilmiştir (Iggers, 2000, s. 52). Febvre'nin meşhur ırmak benzetmesi, onun tarihsel konulara bakış açısını göstermek açısından değerlidir "Bir ırmağı toplumun biri bir engel olarak görürken, başka bir toplum bir yol olarak görebilir. Kolektif tercihi belirleyen etken, son analizinde fiziksel çevre değil insanlardır; insanların hayat tarzları ve tutumlardır" (Burke, 2014, s. 39).

Bloch yargılamak değil anlamak üzere tarihle ilgilenir. Ekonomi tarihi, kırsalın tarihi, coğrafya, antropoloji ilgilendiği bilim dallarıdır. $O$ da Febvre gibi genişletilmiş ve derinleştirilmiş bir tarih anlayışını ve çok disiplinliği savunur (Bloch, 2018, s. 21). Bloch, çalışmalarında çoğunlukla uzun sürenin tarihini esas alır; sorun üzerine odaklanır, toplumsal olgularla ilgilenir ve karşılaştırmalı bir tarih tercih eder. Geriye yönsemeli metod olarak adlandırılan yöntemin tarihi geriye doğru okumak olduğunu, bilinenden yola çıkarak bilinmeyene doğru ilerlemenin daha basiretli bir yaklaşım olduğunu vurgular (Burke, 2014, s. 50). Bu yönteme göre içinde bulunduğumuz zamanı kavramak için bugünden düne bakmak gerekmektedir ve geçmişi anlamadan bugünü anlamaya çalışmak eksik bir yaklaşımdır.

Bloch'a (2018, s. 13-14) göre tarihin merkezinde iki mesele vardır: “Bir yanda zamanın somut maddesi olarak süre; diğer yanda insanların yaşamının bireysel ve kolektif biçimi olarak serüven. Kendilerini aşan sistemler tarafından sürüklenen insanlar, aynı zamanda tarihin hareketliliğini ifadesini bulduğu rastlantı etkeniyle de karşı karşıya kalır." Böylece zaman ve serüveni öncüleyen Bloch (2018, s. 26-27) bu yaklaşımı destekleyen üç sav geliştirir: Birincisi, geçmişi bilmemek şimdiki zamanın anlaşılmasına zarar verir, hatta şimdiki zaman içinde eyleme zarar verir. İkincisi insanın hem zihni bakımdan hem biyolojik açıdan en ince ayrıntısına varana kadar değiştiğinin bilinmesidir: temizlik ve beslenme gibi ihtiyaçlar dahi zaman içinde değişir. Üçüncüsü ise hedeflediği minvalde geniş ve derin bir tarihin tek bir tarihçi tarafından gerçekleştirilemeyecek olmasıdır.

Derginin ikinci dönemi Braudel'in yönetici olmasıyla başlar. Annales'i, siyasal tarihçiliğe isyan eden öncüllerinden ve çağdaşlarından ayıran ve okulun yirminci yüzyıldaki tarihyazımına damga vurması Braudel döneminde derginin izlediği yolun kesin bir formüle edilişi sayesinde olmuştur (Burke, 2014, s. 179). Kurumsallaşma dönemi olarak da adlandırılan Braudel dönemi "yapı" kavramını ön plana çıkarırken çizgisel tarih anlayışının ve gelişmeye olan güvenin terk edilmesini bununla birlikte Batı kültürüne duyulan mutlak inancın da son bulmasını ve farklı kültür ile uygarlıkların karşılaştırmalı olarak değerlendirilmesini sağlamıştır (Iggers, 2000, s. 57). Braudel bölgesel tarih incelemelerine karşılaştırmalı bir yöntemle önem verirken, yüzeysellikten uzak derinlemesine bir araştırma ve geniş ölçekli çalışmalar yapmaktadır. Braudel (2017, s. 21) Maddi Uygarlık'ın birinci cildi olan Gündelik Hayatın Yapıları'nda yöntemini şu şekilde tarif eder:

“Karşılaştırmalı tarih, hiçbir zaman hayal kırıklığına uğratmamış olan uzun süre'nin ve şimdiki zaman-geçmiş zaman diyalektiğinin diline uygun olarak, zaman içinde karşılaştırmalıdır; bu karşılaştırmalı tarih mümkün en geniş mekân boyunca karşılaştırmalıdır; çünkü incelemem, ulaşabildiğim ölçüde, dünyanın tümünü kapsamına almış, "dünyasallaştırılmış”"tır. Her halükârda, doğrudan gözlem ilk safta olmayı sürdürmektedir. Amacım, bizzat hayatın damgası olan, seyirlik şeylerin, kalınlıkların, karmaşıklıkların, türdeş olmamalarını kendilerine bırakarak görmek ve göstermekti. Eğer yaşarken çözmek ve üç katı soyutlamak (bunların yararlı bir sınıflama olduğunu düşünüyorum) mümkün olsaydı, tarih objektif bir bilim olurdu ki, bu hiç de aşikâr değildir."

Hem Akdeniz çalışmasında hem de Maddi Uygarlık adlı üç ciltlik eserinde Braudel'in zaman, mekân ve değişim üzerinden tasnif yaptığ görülmektedir: Coğrafi tarih (durağan zaman), 
toplumsal tarih (ağır ilerleyen zaman) ve bireysel tarih (hızlı akan zaman). Kısa süreli siyasi olayların tarihi olan ve geleneksel tarihyazımının da yöntemini oluşturan bireysel tarihi, olaylar tarihi olarak adlandırmak mümkündür. Coğrafi tarih ise uzun süreli tarih olarak tanımlamanın mümkün olduğu uzun erimli süreçleri kapsayan ve değişimin çok yavaş gerçekleştiği Braudel tarafından kimi zaman jeo-tarih ya da yapı kavramları ile karşılanan tarihtir. Toplumsal tarih ise bu ikisi arasında yer alan, coğrafi tarihe göre daha hılı bir değişim olmakla birlikte yine de bu değişimin yavaş olduğu ekonomi, toplum, uygarlık ve devlet gibi konulara odaklanan orta süreli konjonktür tarihi içinde yer alır. Braudel (2017a, s. 5) zamansallıkları şöyle tarif eder: "(Tarihçiler) zamanın çeşitli zamansallıklar halinde bölünebileceğini iktisatçılardan öğrenmişlerdir ve böylece zaman evcilleşmekte, sonuçta ele gelir hale gelmektedir: uzun veya çok uzun süreli zamansallıklar; yavaş veya daha az yavaş konjonktürler, hızlı, bazıları da anlık olan sapmalar vardır ve bunların en kısa olanları, aynı zamanda saptanmaları en kolay olanlarıdır." Braudel, zamansallıkların tarihini üç katlı bir yapı olarak ele alırken zamansallıkların insanlık tarihinin tamamını yansıtmadığını da belirtir; ortaya çıkan istisnai zaman, yerine ve dönemine göre, bazı mekanlara ve bazı gerçeklere şekil vermektedir. Braudel'in Dünyanın Zamanı adlı kitabına konu olan bu zamansallık meselesi, dünyanın farklı mekanlarının farklı aşamalarda olmalarıyla da açıklanabilir.

Braudel, Febvre ve Bloch'da olduğu gibi tarihsel çalışmanın çok disiplinli olması gerekliliğine dikkat çeker. Tarihçinin ekonomi, etnografi, antropoloji, sosyoloji, dilbilimi, coğrafyacı ve hatta matematik ve istatistik gibi bilim dallarının ayak izlerini takip etmesi ve onlarla temas kurarak deneyim ve araştırmalarından faydalanması gerekliliğini savunur ( Braudel 1958, s. 147). Braudel 1958 (s. 146) yılında yayınladığı bu makalesinde yaklaşık yirmi veya otuz yıldır devam eden sosyal bilimler tartışmalarında, tarihin öneminin ve kullanışlılığının daha özenli vurgulanması gerektiğini söylerken tarihçinin defalarca tekrarladığı çalışmaların toplumsal gerçekliğin ortaya çıkmasını sağladığını belirtir:

"Bizim için toplumsal gerçekliğin merkezinde, tek an ile zamanın yavaşça ortaya çıkışı arasındaki keskin, samimi ve sonsuza kadar tekrarlanan karşıtlıktan daha önemli, gerçekten de merkezi bir şey yoktur. İster geçmişi ister bugünü çalışın, sosyal bilimlerin herhangi bir ortak metodolojisi olacaksa, toplumsal zamanın çoğulluğuna dair açık bir farkındalık kaçınılmazdır."

Burke (2014, s. 80), Braudel'in geleneksel tarım, ticaret ve sanayi kategorilerini ortadan kaldırarak bunların yerine "gündelik hayat"a, insanlara ve şeylere, "insanın yaptığı ya da kullandığı her şeye" eğildiğini belirtir: yiyecek, giyecekler, iskân, aletler, para, kentler vb.. Braudel'in gündelik hayat ve maddi kültüre odaklandığ göz önünde bulundurulduğunda onun kültür tarihçisi olduğunu iddia etmek yanlış olmayacaktır. Gündelik Hayatın Yapıları'nda dile getirdiği gibi gündelik hayatı tarihselleştirmek istemektedir. Bu noktada, çalışmanın konusu gündelik hayatın bir parçası olan yemek kültürü özelinde ekmek ve biranın tarihsel dönüşümü; alım ve satım ile üretim ve tüketimde meydana gelen değişikler hakkında bilgi vermeyi amaçlamaktadır.

\section{Bir Kültür Meselesi Olarak Yemek}

Kültür kavramı, etimolojik olarak toprağ işlemekle ilgilidir. Kavram kökensel olarak ikamet etmek, yetiştirmek, korumak, ibadetle onurlandırmak gibi anlamları içeren Latince 'colere' kelimesinden gelir (Williams, 2012, s. 105). Arapça'da karşımıza çıkan 'hars' kelime ile Türkçe'de kültür ile eşanlamlı kullanılan 'ekin' sözcügü bitki yetiştirmeye işaret eder. On altıncı yüzyılla birlikte, kültür kavramı kişisel görgüye dair davranışları ima eden uygarlık kavramı ile ilişkilendirilerek kullanılmaya başlanır (Smith, 2005, s. 13). 
Antropolojinin temel konuları arasında yer alan kültür kavramına dair Aydınlanma yazarlarından itibaren farklı tanımlamalar yapılmış, ilkel insandan modern insana geçiş aşamalarında insanların bulundukları mekân ve çevreyi algılamaları sonucu belirlenen bir takım davranış kalıpları geliştirilmiş ve sonraki nesillere aktarılmıştır. Aydınlanma döneminde çoğunlukla yazıyla aktarılan "şeyler" kültür olarak kabul edilirken evrimci bir yaklaşıma sahip olan Edward B. Taylor kültürle ilgili genel kabul görmüş tanımını 1871'de yapmıştır: "Bilgilerin, inançların, değerlerin, kuralların, örf ve adetlerin, toplumun üyesi insan tarafından sonradan kazanılmış bütün kapasite ve alışkanlıkların tümü." Taylor'ın yapmış olduğu tanım kendinden sonrakiler için 1şık tutarken aynı zamanda antropoloji çalışmalarına kapı aralamıştır. Taylor'ın yanı sıra farklı yaklaşımları benimseyen araştırmacılar tarafından kültür üzerine değişik tanımlar yapılmıştır.

Marx ve Freud'un kültür tanımları, kültürü inşa eden canlı olan insana odaklanması açısından önem arz eder. Bu iki tanım, insanın yaratıcılığına ve doğa karşısında yaratma ihtiyacına yapılan vurguları nedeniyle tercih edilmiştir. Marx, kültürü doğanın yarattıklarına karşın insanoğlunun yarattığı her şey olarak tanımlar (Güvenç, 2011, s. 23). İnsanın yaratma ihtiyacının kökeninde beslenme ve neslini devam ettirme dürtüleri yatmaktadır. Beslenme ihtiyacının insanın doğaya ve diğer canlılara karşı mücadelesinin temelini oluşturduğunu iddia etmek yanlış olmayacaktır. İlkel insandan modern insana kadar var olan her insanın bu iki temel dürtüsü onların toplum olma ve üretme şekillerine kadar etki etmektedir. Freud ise kültürü şu şekilde yorumlamaktadır: "Kültür, insan hayatının hayvan hayatından sivrilmiş, incelmiş halinden başka bir şey değildir. Bizler bir yandan içgüdü ile yönlendirilmiş, soyaçekimle perçinlenmiş hayvanız, diğer yandan niyet, arzu ve maksat yoluyla yönlendirilmiş ve lisan yoluyla aktarılmış bir kültür mirasına bağımlı, insanız" (Journet, 2009, s. 21). Bu bakış açısına göre, insanı hayvandan ayıran temel noktalardan biri aklını kullanma yetisine sahip olması, diğeri ise üretim, eğitim, sanat ve bunların bir bütünü olan uygarlıkların temel özelliklerini sonraki nesillere aktarım aracı olarak kültürel bir canlı olmasıdır.

Kültürün insanı ilgilendiren birçok konuda bilgi birikimi sunması onun öğretilen bir şey olmasıyla alakalıdır. Öncesinde ve sonrasında doğum ve ölüm ritüelleri, evlilik törenleri, beslenme ve tüketim alışkanlıkları, aile yaşamı, ailede kimin neyi nasıl üreteceği ve iş bölümü gibi gündelik hayata dair konular kültürün bir uzantısı olarak karşımıza çıkmaktadır. Bununla birlikte her birinin kendi içerisinde kendi köken ve nedenleri olan açılamaları bulunmaktadır. Örneğin bir köye ait bir yemek kültüründen bahsedilmesi için, tarihsel bir geçmişi olması gerekmektedir. Gündelik hayata dair bir şeyin kültürel bir mesele olarak ele alınması için kısa süreli bir alışkanlık şeklinde değil uzun süreli bir alışkanlık ve devamlılık göstermesi gerekmektedir. Bununla birlikte kültürler uyum ve dönüşüm potansiyeline sahiptir; kültürler arası etkileşimle birlikte kültür dönüşebilir ve değişebilir (Kartari, 2014, s. 33). Yine yemek kültürü üzerinden örnek vermek gerekirse, komşu köyler arasındaki iletişim, onların arasında bir kültür aktarımı olmasına vesile olabilir ve yemeğin üretilişinde veya içine katılan çeşnilerde değişiklik meydana gelebilir.

Gündelik hayata dair konuların kültürel tarih olarak incelenmesinde sosyologlar, tarihçiler ve antropologlar önemli bir yer tutar. Klasik sosyolojinin önemli isimleri olarak kabul edilen isimlerin çoğu kültür kavramını kullanmasa da kültürel çözümlemeler yapmışlardır. Bir örnek vermek gerekirse, Burke (2008, s. 15), Max Weber'in ünlü Protestan Ahlakı ve Kapitalizm'in Ruhu adlı kitabının aslında Batı Avrupa ve Amerika'nın ekonomik sistemlerinin kültürel bir çözümlemesi olduğuna, kitabı Kapitalizm ve Protestanlık Kültürü ya da Protestanlık ve 
Kapitalizm Kültürü olarak adlandırmanın mümkün olduğunu iddia eder. Benzer bir iddiayı Burke, Annales yazarları için de yapar. Burke (2008, s. 5) , Annales'in gündelik hayata ilişkin maddi ve manevi kültürle ilgili konularda açıklayıcı eserler yaptıklarını ancak bu çalışmalarında kültür kavramına yer verilmediğini, kültür yerine uygarlık, ortak zihniyet, toplumsal imgelem kavramlarının daha çok tercih edildiğini belirtir. Aynı şeyden farklı kavramlar adı altında bahsedilebilmesine fırsat sunan şey hem kültür kavramının hem de yerine ikame edilen kavramların soyutluğundan kaynaklanmaktadır.

İnsanlı̆̆ın yüzlerce yıllık tarihsel birikiminin ürünü olan yeme-içme olgusu, üretiminden tüketimine geniş bir süreç içinde iktisadi, kültürel, toplumsal yapılarla ilişkiye girerek sosyal bilimlerin ilgi alanına girer. Bu bakımdan, "merkezi konumu nedeniyle yemek tarihi 'diğer' tarihlerle birlikte ilerler, onları belirler ve onlar tarafından belirlenir" (Montanari, 1995, s. 13). Neolitik dönemle birlikte üretime geçen insanın beslenme kültürü avcı-toplayıcılıktan üreticiliğe geçiş şeklinde değişmiştir. Bu süreç sosyal ve kültürel gelişim açısından önemlidir. Örneğin Bereketli Hilal olarak bilinen, Doğu Akdeniz kıyıları ve Mezopotamya ile Çin'in bazı bölgeleri, tarıma geçişin ilk görüldüğü bölgelerdir. Bugün dünya nüfusunun yüzde doksanı, kökleri bu iki tarımsal bölgeye dayanan yedi dil ailesinden birine bağlı bir dili konuşmaktadır (Standage, 2016, s. 41-42).

Neolitik Dönem, insanlığın avcı-toplayıcılıktan tarım toplumuna ve yerleşik yaşama geçtiği aşamadır. Bu dönemi karakterize eden olgular, bitki ve hayvanların evcilleştirilerek tarım ve hayvancılık yapılması, tarımı kolaylaştıran taş aletlerinde teknolojik ilerleme ve insanlığın bunları yapması için gereken yerleşikliği göstermesidir. Yerleşik yaşama geçiş, insanlığın sosyo-ekonomik, siyasal ve düşünsel yapısını biçimlendiren dinamik ve girift bir süreçtir. Bu dönemden itibaren insanlığın bitki, hayvan ve doğa ile kurduğu ilişki tamamen değişmiştir. Childe' in (2010, s. 54-55) ifade ettiği gibi:

“İnsan ekonomisini tümden değiştiren ilk devrim, insanı besin kaynağına başat kılmıştır. İnsan ekip biçmeye, bitki yetiştirmeye seçmesini bilerek yenilebilir ot, kök ve ağaçları geliştirmeye başlamıştır.

Karşılığında besin, barınak ve bakım sağlayarak bazı hayvanları evcilleştirmeyi ve kendine bağlamayı da başarmıştır. Bugün bize de dek varan yüce bir kültür birikimine en çok katkıda bulunan uygarlıklarda ekonominin temelinde buğday ve arpa vardır."

Geçmişleri erken Neolitik döneme uzanan buğday ve arpa maddelerine dayanan ekmek ve bira, insanlı̆̆ın ilk ürettiği besinlerdendir. Ponting (2008, s. 53), tarımın ilk ortaya çıktığ bölgelerde buğday ve arpanın ehlileştirilmesinin eş zamanlı olduğuna dikkat çeker:

“En önemli ekin, tahıllar arasında besin değeri en yüksek tür olan buğdaydı. İlk olarak ehlileştirilen buğday cinsleri artık ekilmiyor fakat Ortaçağ'da İngiltere'de hala yetiştiriliyor olduklarını biliyoruz... Arpa ise, sert iklime karşı buğdaya oranla daha dayanıklı olmasına karşın, ekmek pişirmekten çok, bira yapımı için saklanıyordu."

Bober (2014, s. 89), Mısır uygarlığında ekmek ve bira arasındaki ilişkinin niteliğini “tavuk mu yumurtadan, yumurta mı tavuktan çıtı?" sorusuyla anlamlandırır. Mezopotamya uygarlığına gelince, insan kültürünün ilk yaratısının bira olduğunu belirtir. Dolayısıyla yemeiçmeye ilişkin güçlü anlamlar barındıran ekmek ve biranın ekonomik, kültürel ve toplumsal yapılarla girdiği ilişkiyle geçirdiği değişim süreci yemeğin kültürel tarihini anlamaya yönelik önemli ipuçları barındırır.

\section{Ekmek}


Bitkilerin evcilleştirildiği neolitik devrimin en önemli sonuçlarından biri beslenme kültürünün en gündelik öğesi olan ekmekte açığa çıkmaktadır. Milyonlarca yıl doğada hazır halde bulunan bitkiler artık yemek için dönüştürülmeye başlanmıştır. Bu süreç uzundur:

"Tahılların yenilebilmesi için tohumların toplanması, harman dövülmesi ve harman savrularak tahılların kabuklarından arındırılması, daha sonra tohumların ögütülerek una dönüştürülmesi, suyla karıştırılıp bir hamur hazırlanması, hamurun mayalanması ve pişirilmesi gerekir. Ancak tüm bu çabaların sonucunda lezzet ve besin değeri açısından elde edilen ödül o kadar büyüktür ki ekmek kelimesi zamanla yemek kelimesiyle eşanlamlı olarak kullanılmaya başlanmıştır" (Silvertown, 2018, s. 53).

Bununla birlikte, ekmek yapımında kullanılan buğdayın ilk kez M.Ö. 6000 yıllarında Kuzey İran'da düşük kaliteli buğday ile yabani buğdayın melezleştirilmesiyle elde edildiği bilinmektedir (Ponting, 2008, s. 57) Eski toplumların yeme içme davranışları açısından ortak özelliği, toplumsal konum ile tüketimin paralel olmasıdır. Köle ya da işçilerin beslenme düzeninde ekmek ve bira yer almaktadır (Bober, 2014, s. 53). Hitit uygarlığında en çok tarımı yapılan ürünlerin başında ekmek ve biranın ham maddesi olan arpa ve buğday gelmektedir. Çeşitli adlar verilen 180'e yakın ekmek bulunması Hititlerdeki ekmek zenginliğini gösterir (Işın, 2019, s. 55). Eski uygarlıklarda temel besin maddesi olmanın yanında kutsal sayılan ve tapınaklarda adak olarak yer bulan ekmek ekonomik değer de taşıyordu. Örneğin Mezopotamya'da para icat edilmediğinden işçilerin maaşları tahıl ve bazen ekmek olarak ödeniyordu (Işın, 2019, s. 37).

Eski Mısır ve Mezopotamya'da ekmek ve bira para yerine kullanılmanın dışında ilaç olarak tıp alanında da yer bulmuştur. Toplumu sosyal, dinsel ve ekonomik açıdan kuşatan "ekmek ve bira" birbirine bütünleşik şekilde gündelik hayatın içinde genel olarak "besin" adıyla kavramsallaştırılmıştır. Örneğin Eski Mısır' da "ekmek ve bira" ifadesi, birisine iyi şans ya da şifa dilemek gibi gündelik bir selam olarak kullanılmaktadır. "Ziyafet"in karşılı̆̆ Sümerce bir sözcük, "biranın ve ekmeğin yeri" anlamına gelmektedir (Standage, 2014, s. 46).

Antik Mısır' da ekonomi takas üzerine kurulmuştu ve tahılların miktarı ne kadar ekmek veya bira üretilebileceği hesaplanarak biçiliyordu (Işın, 2019, s. 54). Mezarlara konulan ekmek toplumun bütünü için temel besin maddesi olsa da kalite açısından ekmekler farklılaşıyordu. Halk kaba ögütülmüş kepekli arpa veya buğday ekmeği yerken zenginlerin ekmeği, ince ögütülmüş ve elekten geçirilerek kepeği alınmış undan yapılıyordu. Zenginlerin ekmeğine bal, hurma, sarımsak gibi malzemeler ekleniyordu (Işın, 2019, s. 47) Sümer beslenme kültürü ekmek ve bira arasındaki yakın ilişkiyi göstermesi açısından dikkat çekicidir. Zira bu uygarlıkta arpadan elde edilen malttan yapılan ekmek, bira haline getiriliyordu (Işın, 2019, s. 40).

Hititler ve Urartular gibi ilk Anadolu uygarlıklarında da ekmek kutsaldı ve kurban törenlerinde bulundurulurdu (Standage, 2014, s. 59). Antik Yunan döneminde tahillar arasında özellikle buğday ve arpa beslenmenin vazgeçilmez öğelerinden biriydi. Sparta'da yemekten sonra tatlı niyetine buğday ekmeği ikram ediliyordu (Friedell, 1999, s. 39). Atinalı Solon'un çıkardığı yasalara göre mayalanan hamurla yapılan ekmek festivallerde satılmaya başlanmıştır. Antik Yunan gibi Roma'da da ekmek temel gıda maddesiydi. Hıristiyanlık gelişirken Akdeniz uygarlığının maddi ve ideolojik simgelerini içermiştir. Dolayısıyla Roma için önemli olan zeytinyağı ve şarapla birlikte ekmek de ideolojik simge ve ibadet aracına dönüşür. Hıristiyanlık kozmolojisinde İsa'nın vücudunu temsil eden ekmek dini ritüellerin bir parçasıdır. Augustinus'un bir vaazında, ekmek yapımıyla birinin yeni Hıristiyan oluşu 
arasında kurduğu metaforik benzerlik ekmeğe duyulan saygınlığı göstermesi bakımından önemlidir (Montanari, 2018, s. 31).

Hıristiyanlığın mutfak kültürü üzerinde etkisi Antik Yunan, Roma ve Anadolu kültürüne dayanan Bizans uygarlığında da görülür. Değişik türlerde yapılan ekmekler arasında iki kez fırınlanan peksimet ekmeği uzun süre dayandığı için özellikle askerler ve gemicilerin kullandığı pratik bir besindir. Anadolu'nun temel gıda maddesi olan ekmek, Selçuklu ve Osmanlı döneminde çeşitlenerek üstünlüğünü korumaya devam etmiştir. Ortaçağ Avrupası'nda ise mayalanmış buğday ekmeği şehirlilere ve seçkinlere özgü bir gıdaydı. 19. yüzyılın ortasına kadar Avrupa'nın birçok bölgesinde toplumun alt kesimleri ender olarak mayalanmış ekmek yiyebilmişlerdir (Işın, 2019, s. 323).

Bloch, Ortaçağ Avrupa'sında önemli bir yere sahip olan lord kelimesinin etimolojik kökeninin "ekmek veren" anlamına geldiğine dikkat çeker. Lordun sadece askeri bir sorumluluğunun olmadığını aynı zamanda kendine bağlı olanları doyurmakla da sorumlu olduğu gerçeğinden hareketle ekmek veren anlamına gelen lord kelimesi kullanılır. Aynı şekilde lordun evinde toplanan adamlara da "ekmek yiyiciler" (hlafattan) denilmesi ekmeğin Ortaçağ Avrupası'ndaki yerini göstermesi açısından önemlidir (Bloch, 2019, s. 229). Bloch (2019, s. 312) aynı çalışmasında, Ortaçă̆ senyörlerinin köylüler aleyhine vergi oluşturabilmek için bazı ürünlerin üretimini kendi tekellerine aldıklarını ve bunlar arasında bira ve şarap satış hakkının bulunduğunu belirtir.

Ekmek, üretiminden tüketimine içinde bulunduğu toplumlarda kültürel sınırların simgesi olmuştur. Bitkilerin ehlileştirilmesinin ürünü olan ekmek yapımı, benimsendiği toplumlarda bir uygarlık işaretidir. Buna göre tahılın olduğu gibi tüketilmesi ile pişirilerek ekmek halinde yenmesi biz ve onlar ayrımı üzerinden kültürel kimliğin parçası kılınmıştır (Montanari, 2018, s. 20-21). Örneğin Avrupa'da ekmeğin rengi algılanmasını ve tüketimini sosyo-ekonomik sınıflar arasında farklılaştıran bir unsurdur. Beyaz olan buğday ekmeği üst sınıflar için üretilirken çavdar ve diğer tahıllardan üretilen rengi esmer olan ekmeği ise köylülerle hizmetçiler tüketiyordu (Montanari, 2018, s. 50). Bununla birlikte, beyaz ekmeğin büyük olasılıkla icat edildiği on dördüncü yüzyıldan sonra kıtlık dönemlerinde beyaz ekmek tüketimine de sinırlandırmalar getirildi: unun tamamını kullanılarak yapılan, unun içerisindeki kepek ve tohumların çıkarılmasıyla elde edilen beyaz ekmek, on dokuzuncu yüzyıla kadar lüks bir tüketim olarak görüldü. On dokuzuncu yüzyılda tahıl kaynaklarının artmasıyla yaygınlaşan beyaz ekmek yirminci yüzyılda piyasaya hakim oldu (Ponting, 2008, s. 276).

Braudel (2017b, s. 23) ekmeğin modernlikle olan ilgisini Londra kentinin gelişmesi örneği üzerinden değerlendirir. Erken modern dönemde Londra'nın zenginleşmesini tarif ederken, kırsalda yeni gelişen zengin sınıf kadınları hizmetçileri olan, iyi giyimli ve beyaz ekmek yiyen kadınlar olarak tarif eder. Böylece beyaz ekmek tüketmenin zenginlik ve modernlik göstergesi haline gelmesi Braudel'in örneğinde tekrar ortaya çıkar. Yine Braudel (2017b, s. 152), Quesnay'ın 1766 yılında yazmış olduğu ve tüketimde lüks olarak görülen şeylere dikkat çekerken, beyaz ekmek tüketiminin o tarihlerde nasıl bir zenginlik emaresi olduğunu gösterir: "Yalnızca kara buğday ekmeği yiyen ve su içen, ama beyaz ekmek yemek, şarap içmek isteyen; et yiyemeyip, yemek isteyen; yalnızca kötü elbiseleri olup, iyilerine sahip olmak isteyen; ısınmak için odunları olmayıp, satın almak isteyen vb. tüketiciler." 
Ekmeği, kültürel kimliğin yanı sıra farklı uygarlıkların yeme alışkanlıklarının da bir parçası olarak görmek mümkündür. Bu kapsamda, 1400-1740 yılları arasında Avrupa'nın büyük bir ekmek tüketicisi olduğu ve vejeteryan oldukları iddia edilebilir (Moore, 2003, s. 444). Ponting (2008, s. 123), Avrupalıların çoğunun sebze, tahıl lapası ve ekmekten oluşan tek düze beslenme biçimine sahip olduğunu, 1870 gibi geç bir tarihte bile Fransız beslenme biçiminin \% 70'nin ekmek ve patatesten oluştuğunu belirtir. Ponting (2008, s. 383) ayrıca on dördüncü yüzyıl veba salgınından sonra Avrupa'nın beslenme alışkanlıklarının çeşitlendiğini, ancak özellikle 15001800 yıllarında çeşitliliğ̈in azaldığını belirtir. Buna rağmen, Ortaçağ'da ve erken modern dönemde Avrupa'daki harcamaların çoğunluğu (\%80) gıdaya giderken bu harcamaların yarıya yakını da ayda bir ya da iki kere pişirilen ekmekten oluşuyordu (Ponting 2008, s. 383). Harcanan paranın büyük bir kısmının ekmeğe gitmesi yemek kültüründe ekmeğin yerini göstermesi açısından hem de ekonomik önemini anlamak açısından önem arz eder. Yine Ponting' in çalışmasından yola çıkarak ayda bir ya da iki kere olan ekmek üretiminin herkesin evinde fırın olmaması nedeniyle genellikle toplu halde yapılmasını kolektivitenin bir yansıması olarak görmek mümkündür. Her evde fırın olmadığı bilgisi ise, ekmeğin pazar değeri olan bir ürün olduğunu göstermesi açısından önemlidir.

Ekmeğin nerede satıldığı, ticarileşmesini göstermesi bakımından önem arz eder. Fırıncıların, kentlerin ortaya çıkmaya başladığı zamandan itibaren zanaatkar sınıflar arasında yer almaya başladığı bilinmektedir. Fırıncıların ürettikleri yerin dışında pazarda satış yapması da pazarların gelişmesiyle ortaya çıkmaya başlamıştır: zanaatkar oldukça erken bir tarihten itibaren, pazar kurulmadığı günlerde kendi dükkanında, o zaman söylendiği üzere, "kendi penceresinden" satış yapacaktır. Böylece bir orada, bir burada gerçekleşen bu faaliyet, dükkanı biraz pazar gibi, kesintili bir satış yeri haline getirecektir (Braudel, 2017b, s. 48). Braudel ayrıca Paris örneğinde fırıncıların vasat ve lüks ekmeği dükkanlarında, kaba ekmeği de pazarda satmayı tercih ettiklerini de söyler. Pazar kültürünün gelişmesi ile kentli zanaatkar kültürünün gelişmesi ekmeğin üretimi açısından önem arz eden bir konudur. Pazara yeteri kadar ekmek götürmemek ya da ekmeğin fiyatlarıla oynamak pre-kapitalist dönemden itibaren fırıncıların yapmaya başladığı bir alışkanlıkken, yönetimlerin ekmek ve fiyatlara bazı zamanlarda müdahale ettiğinin bilinmesi, ekmeğin yaşamsal önemini gösterir. Firıncılığın bir zanaat olarak ele alınmasına karşın, Braudel (2017b, s. 261-263), fırınları kapitalist yeniliklere dirençli, on dokuzuncu ve yirminci yüzyıla gelene değin geleneksel yapısını koruyacak olan aile tipi işletmeler olarak görür ve bu zanaatın pazarın alışılmış kurallarını yarı yarıya 1skaladığını belirtir.

Braudel ekmek konusunu ekonomilerin durağanlaşması ve büyümesi üzerinden de ele alır: Büyüme dönemlerinin kendi içerisinde durgunluklar barındırdığını, kalkınma dönemlerinin de durgunluklar ve gerilemelere sahip olduğunu belirttikten sonra her ne kadar beslenme alışkanlıkları gerilemiş olsa da eskiye oranla görece büyüyen ekonomiler sayesinde Batılı insanın, on beşinci yüzyıla değin hiç o zamanki kadar ekmek ve et yeme imkanının olmadığını belirtir (Braudel, 2017a, s. 261). Ayrıca ekmeğin bir tüketim malı olması da onun kapitalizmle birlikte dönüşmesi ve pazarda satılan bir ürün haline gelmesiyle sonuçlanır. Tarlaya ekilen buğday bir kapitaldir ancak ekmek olarak yenen buğday üretim dışı bir yapıya sahiptir (Braudel, 2017b, s. 209). Ekmeğin pazar için üretilmesiyle birlikte bu durum da değişikliğe uğramış ve ekmek piyasa ürünü haline gelmiştir.

Ekmek aynı zamanda diğer tarıma bağlı ürünler gibi toplumsal istikrar için mühimdir. İklim koşullarına bağlı olarak kötü geçen bir hasat dönemi, kaynakların azalmasına neden olabiliyor 
bu da nüfusun yetersiz beslenmesine ve fiyatların artış göstermesine yol açıyordu. Bu ise başta köylü sınıfı olmak üzere tüm toplumu olumsuz etkiliyebiliyordu. Üst üste kötü giden birkaç hasat dönemi nüfusun yoksullaşmasına, şehirlerde ise ekmek dahil temel gida maddelerine ulaşımın zorlaşmasına neden olabiliyor bu da salgın hastalıklara direnci düşürürken aynı zamanda toplumsal huzursuzlukları da beraberinde getirebiliyordu. Ponting (2008, s. 118) hasat ve toplumsal huzursuzluklar için temel kıstas olarak ekmek ve tahıl fiyatlarının önemine şöyle dikkat çeker: "Hemen hemen bütün yönetimler, ülkedeki hava durumu, hasat beklentisi, toplumsal huzursuzluk düzeyinin ana göstergelerinden olan tahıl ve ekmek fiyatları ile ilgili ayrıntılı raporlara büyük önem veriyordu."

\section{Bira}

Üretimi tahıl maddesine dayanan biranın nasıl keşfedildiği tam olarak bilinmemektedir. Yapılan çalışmalar biranın orijini için Mezopotamya'yı işaret etmektedir. Kaynağı ortak olan bira ve ekmek hem beslenme kültürü açısından hem kutsallıkları açısından birbirinin yerine geçmektedir. İlk tahılların ekmek üretmek için değil bira mayalamak için yetiştirildiğini öne süren görüşler mevcuttur (Silvertown, 2018, s. 199). Fakat genel olarak ekmeğin mi biranın mı daha önce yapıldığı kesinleşmemiştir. Kesin olan ise biranın -doyurucu özellik taşıdığı içingünlük hayatın vazgeçilmez besin maddesi olduğudur. Ekmekle birlikte en çok tüketilen besinlerden biridir. Tüketimini arttıran nedenlerden biri sarhoş olmanın dinsel bir davranış kabul edilmesiyle biranın tanrılara hazırlanan şölenlerde yer bulmasıdır.

Biranın genellikle arpadan üretildiği kabul edilmektedir. Bununla birlikte çeşitli ürünlerin farklı yer ve zamanlarda mayalandırılarak bira yapımında kullanıldığ 1 bilinmektedir. Eski Mısır, Babil ve Çin gibi eski uygarlıkların her birinde biranın varlığı bilinmektedir. Ancak biranın hammadesi farklılık gösterebilmektedir. Braudel (2017, s. 216) biranın farklı yerlerde farklı mayalandırılmasına şu şekilde dikkat çekmektedir:

"Bira imal etmek için buğday, yulaf, çavdar, darı, arpa veya hatta karabuğday mayalandırılmaktadır. Hiçbir tahıl asla tek başına işlemden geçmemektedir: bira imalatçıları bugün malt, şerbetçiotu ve pirinç katmaktadırlar. Ama dünkü reçeteler çeşitliydi ve bira horozibiği, mantar, aromalı bitkiler, bal, şeker, defne yaprakları... ile daha cazip hale getirilmekteydi. Çinliler de darı veya pirinç "şarapları"na aromatik katkılar, hatta eczalar ilâve etmekteydiler. Bugün Batı'da genelleşmiş olan şerbetçiotu (biraya acılığını sağlamakta ve muhafazasını mümkün kılmaktadır) kullanımı, VIII. veya IX. yüyıl manastırlarından kaynaklanmış olmalıdır (ilk zikredilme tarihi 822); şerbetçiotu kullanımı XII. yüzyılda Almanya'da; XIV. yüzyılda Alçak Ülkeler'de işaret edilmiştir; İngiltere'ye geç olarak, XV. yüzyılın başında ulaşmıştır."

Biranın izini, ekmekle birlikte ilk uygarlıklara kadar sürmek mümkündür. Örneğin Sümer panteonunda bira ve ekmek başat role sahiptir. Burada bira yapımı kadınların tekelindeydi ve kadınlar bira üretirken tanrıçaların koruması altındaydı (Kempen, 2018 s. 73). Tanrıçalar arasında en meşhuru Ninkasi adında bira yapımından sorumlu özel bir tanrıçadır. Sümerlere ait Gılgamış Destanı'nda yarı insan yarı hayvan olan Enkidu ekmek ve bira sayesinde tam bir insana dönüşür. Diğer bir ifadeyle Gılgamış Destanı'nda ekmek ve bira tüketmek medenileşme göstergesidir. Sümerler'de Ninkasi'den başka Gılgamış Destanı'nın onuncu tabletinde Siduri adında tanrısal şarap yapımcısından bahsedilir: "Deniz kenarında bağcı ve şarap yapımcısı Siduri yaşıyordu. Tanrıların kendisine verdiği kocaman altın fıçılar, altın testiler yanı başında Denizin kenarındaki bahçede oturuyordu..." (Gezgin, 2009, s. 85). Yine Mısır'da ölüler dünyasının tanrısı ve yeryüzündeki yaşamın kaynağı olan Osiris'in şarabı ve birayı insanlara hediye etmiş olduğuna inanılırdı (Phillips, 2016, s. 20). 
Eski uygarlıklarda -Mezopotamyalılar, Mısırlılar, Hititler- tüketilen bira kıvam ve yapılış açısından bozaya benziyordu ve kamışla içiliyordu. Birden fazla kişinin kamışla aynı kaptan içme ritüeli bira içme eyleminin doymaktan çok toplumsal davranışın temel olgularından biri olmasından gelmektedir. Nitekim döneme ait bira içme tasvirlerini içeren mühürlerde ve mezarların içinde değerli metallerden yapılma kamışların olması biranın toplumsal kutlamalarda ve dini törenlerde yeri olduğunu gösterir (Işın, 2019 s. 41-42). Hitit tapınaklarında bira imalathanesinin olması biranın dinsel örüntülerdeki yerini göstermesi bakımından önemlidir.

Ege'ye doğru yaklaştıkça içeceklerle ilgili tutum değişmeye başlar. Friglerde şarap, bal şarabı ve bira ayrı ayrı veya üçünün karışımı şeklinde içiliyordu. Ege bölgesinde şarapcılık geliştikçe bira ve bal şarabı giderek "barbar" insanların içkileri olarak küçümsenir, şarap ise "medeni" insanların içkisi sayılır (Işın, 2019 s. 65). Bu düşüncenin billurlaştığı uygarlıklar Yunan ve Roma olmuştur. Buralarda, Anadolu, Mezopotamya ve Misır'da biraya verilen önem yerini şaraba bırakmıştır. Yunan kültüründe şarap erkek içkisi kabul edilirken, bira kadın veya efemine içkisi olarak görülüyordu (Phillips, 2016, s. 39). Romalılar da şarabı biraya tercih etmişler ve başka kültürleri ne içtiğine, nasıl içtiğine göre yargılamışlardır (Phillips, 2016, s. 40). Şarap, Bizans kültüründe de öne çıkan içki olmuştur.

Eski dönemlerde biraların yapım tekniği Mısır, Sümer ve Hititlerde aynıdır. Tortulu bir yapıya sahip boza kıvamındaki biralar bu uygarlıklarda pipet ile içilmektedir. Antik dönem biracılığının yapım ve kullanılan malzeme açısından farklılaşması Ortaçağ'da zamana yayılarak olmuştur. Biranın besin olarak algılanması belli bir dönem devam etmiştir:

"Alkol hem keyif verici madde hem de besin maddesidir. Ortaçă̆'da insanlar, o dönemde sayıları hayli fazla olan bayramlarda (örneğin 1660'da Paris'te yılda 103 gün bayram kutlanır), kilise ayinlerinde, düğünlerde, vaftiz törenlerinde, cenazelerde, Mavi Pazartesilerde vs. şarap ve birayla sarhoş olurlar. Kalan iş günlerinde de bira ve şarabı beslenmenin bir parçası olarak tüketirler" (Schivelbusch, 2000, s. 30).

Biranın günlük yaşama bu derece eklemlenmesinde Avrupa'da yaşanan temiz su sıkıntısının etkisi büyüktür. 1200'lü yıllarda Kuzey Almanya'da bira üretiminde şerbetçiotunun kullanılmaya başlanması biranın dayanıklılığını arttırarak ticari değer katmıştır (Phillips, 2016, s. 77). Şerbetçiotu aynı zamanda bira sanayisinin ortaya çıkmasına zemin hazırlamıştır. İçeriği ve üretim şekli değişen bira pazarda yer bulmasıyla birlikte kültürel anlamı ve tüketim bağlamı değişmeye başlar. Kuzey Avrupa'da yapılan kazılarda yerleşim yerlerinde bir maltlama fırını ve arpa tanelerine rastlanması ekmek pişirmenin ve bira yapmanın birbirinden ayrı işleyen süreçlere dönüştüğünü göstermesi bakımından önemlidir. Evlerde üretilen ekmek ve bira, gündelik ev işlerinin parçası olarak kadınların tekelindedir (Kempen, 2018, s. 75). Kapitalizme geçişle birlikte, emeği değersizleştirilen kadınlar bira gibi kendilerine özgü işlerden de dişlanır (Federici, 2012, s. 138). 1400 ve 1500'lerde erkeklerin ticari bira üretimi yaptığı bir kültür ve ekonomi düzeni ortaya çıkmıştır. 1500'lerde bu değişim çeşitli kurumsal şekiller almış, birçok yönetici bira üretim endüstrisinin üretim ya da satış fark etmeksizin pek çok safhasında kadınları dışlamaya başlamıştır (Phillips, 2016, s. 76).

Bira üretiminin mekanını değiştiren ilk modern tesisler erken Ortaçağ döneminin manastırları olmuştur. Zira manastırlar ticari üretim için gerekli malzemeleri alma hususunda yeteri derecede zengin olmanın yanı sıra aynı zamanda gerekli tahıl ihtiyacını karşılayacak arazilere de sahiptir (Phillips, 2016, s. 62). Ortaçağ manastırlarında, eski dönemlerde olduğu gibi bira üretim yerleri fırınla aynı yerde bulunur (Bober, 2014, s. 289). 1040 yılında eski bir manastırda 
kurulan bira firması Weihenstephan hala üretime devam etmektedir (Kempen 2018, s. 76-77). Geç Ortaçağ dönemi ise temiz su kaynağı sıkıntısı nedeniyle su yerine düşük alkollü bira içildiği bir dönem olmuştur. Sudan daha temiz olmasının etkisiyle bira, çocukların beslenme düzeninde belli oranlarda yer bulmuştur (Genç, 2016, s. 257).

Braudel, pre- kapitalist dönemde kurulan imalathaneleri ve zanaatları incelerken bira yapımını ve bira üretilen yerleri inceler. Fırın, tuğla, fayans gibi diğer imalathanelerin yanı sıra bira imalathanelerinin de zorunlu hizmet kapsamındaki emek gücüyle üretim yaptığ ve bedava hammadde kullandığını belirtir. Endüstriyel üretim tasniflemesinde ise bira imalathanelerine, farklı ülkelerde farklı tarihlerde gerçekleşmekle birlikte "bir araya toplanmış imalathaneler" kategorisinde yer verir (Braudel, 2017b, s. 265): “Bunların karakteristiği, az veya çok geniş olan binalarda, emek gücünü biraraya toplamış olmalarıdır; bu emeğin gözetimine, daha ilerlemiş bir işbölümüne, kısacası artan bir üretkenliğe ve ürün kalitesinin yükseltilmesine olanak vermektedir." Braudel (2017b, s. 299) ayrıca, uzun süre bir zanaat olarak kalan bira imalathanelerinin büyümesi ve çok büyük miktarlarda bira üretecek kıvama gelmesi için çok fazla sermayeye ihtiyaç duyduğunu da belirtmektedir.

Bira veya şarap dahilinde alkollü içeceklerin Avrupa'da yükselişi on yedinci yüzyıla tekabül eder. Braudel'in dikkat çektiği üzere aslında on altıncı yüzyıl alkolü yaratır, on yedinci yüzyıl onu ilerletir, yükseltir ve on sekizinci yüzyıl alkolü avamlaştırır. On altıncı yüzyılda Avrupa genelinde alkol satışlarındaki artışı bu minvalde değerlendirmek mümkündür. Aslında bira, diğer bölgelere oranla daha çok Kuzey ülkelerinde kendi evindedir (Braudel, 2017, s. 216). Bira üretiminin kurumsallaşması ve meslek haline gelmesiyle bira imalathaneleri ve alkollü içki satışı yapan hanlar ortaya çıar ve erkekler kadınların yerini almaya başlar (Kempen, 2018, s. 79). On yedinci yüzyılda yeni içkilerle tanışıldıktan sonra biranın toplumdaki yeri değişmeye başlar. Schivelbusch (2000, s. 42) bu değişikliği kalkınmış bir toplum ve ekonomi, davranışların değiştirilmesini dayatan olay ve durumlar, daha fazla çalışma disiplini, ayrıca eskilerin yerini alacak yeni içeceklere yani on yedinci yüzyılda Avrupa'ya yeni gelen sıcak içeceklere -özellikle kahveye- bağlar. Konuyu başka bir açıdan ele alan Braudel (2017, s. 218) ise şarabın bira ile rekabet edebilir olmasını, üretildikleri hammaddeye bağlar ve bira demenin tahıl demek olduğunu, onu içmenin bazen ekmeksiz kalmakla sonuçlanabileceğine dikkat çeker.

Besin olarak kabul edilmeyen damıtılmış alkollü içecekler ve alkolsüz sıcak içeceklerin yaygınlaşmasıyla şarap ve biraya içkin kültür arkaik anlamlarından arınmış olsa da izleri halen sürülebilir:

“Modern Avrupa'nın içme kalıpları birinci binyılın ortalarında kristalleşti ve büyük ölçüde Yunan va Roma etkisinin ulaşmasıyla belirlendi. Genellikle makul sınırlar içinde ve yemeklerle birlikte şarap içmek Roma İmparatorluğu'nun eski sınırlan içinde bulunan Avrupa'nın güneyinde hala egemendir. Roma'nın menzili dışında kalan Kuzey Avrupa' da ise yemeksiz bira içmek daha yaygındır" (Standage, 2014, s. 92).

\section{SONUÇ}

Faulkner, tarih boyunca iki büyük devrimden ilki olarak Tarım Devrimi'ni ikinci olarak ise Sanayi Devrimi'ni görür. Tarım devrimiyle birlikte, arpa, esmer buğday, sığır, domuz ve koyunlar ehlileştirilmeye başlanmış ve çiftçiliğin gelişmesiyle tarımsal devrim farklı zamanlarda da olsa tüm dünyayı etkisi altına almıştır (Faulkner, 2013, s. 183). Sanayi Devrimi ise ticari kapitalizm döneminin ardından üretim şeklinin değişmesi ve imalattan fabrika 
sistemine geçişle yaşanmıştır. Pre-kapitalist dönemde ticaret kapitalizmiyle birlikte malların mübadelesi ve paranın dolaşımında artış yaşanırken üretim küçük imalathanelerde ya da geleneksel zanaatkarlar tarafından yapılmaya devam etmiştir. Sanayi Devrimi ise fabrikasyon üretime aşamalı olarak geçiş ile sonuçlanmıştır.

Bu çalışma, Sanayi Devrimi'ne kadar ekmek ve biranın üretimindeki çeşitliliğe yer verirken Sanayi Devrimi sonrası üretimsel farklılaşmalara yer vermemektedir. Çalışmanın temel hipotezlerinden biri, Tarım Devrimi'nden Sanayi Devrimi'ne kadar ekmek ve biranın tarihselliğinde üretimsel olarak çok büyük farklılaşmaların meydana gelmediğidir. Ancak prekapitalist dönemle birlikte imalathanelerin büyümeye başlaması ve sayıca artışıla birlikte geleneksel üretimi farklılaşmış, Sanayi Devrimi'nin ardından fabrika üretimine geçiş kültürel üretimden seri üretime geçişi beraberinde getirerek üretimdeki işgücü dağılımını yeniden düzenlemiştir. Bütün bunlarla birlikte Annales'in modernleşme/kapitalizm tarihi okuması, yemeğe içkin kültürün değişimini anlamlandıran bir olgudur.

İnsanlığa Neolitik dönemden beri eşlik eden ekmek ve bira, her ikisi de tahıl maddesinden yapılan ve tat açısından büyük benzerlik taşıyan besinlerdir. Yeme-içme kültürünü ele alan çalışmalarda, birinden bahsederken ötekinin anmamanın güç olduğu söylenebilir. Standage'nin (2014, s. 27) ifadesiyle "aslında ikisi de aynı madalyonun iki yüzüydü: Ekmek kah biraydı, bira ise sıvı ekmekti." Yüzyılların birikimini taşıyan bira ve ekmek, üretildiği ilk uygarlıklarda bayramlarda, dini törenlerde, ölü gömme törenlerinde ve günlük hayatta çok önemliydi. Ekmek tarih boyunca olumlu imajını korurken, biranın kültürel açıdan sembolik değeri değişikliğe uğramıştır.. Buna göre, sanayileşme hammaddeye dayanan bira ve ekmeğe ilişkin üretim ve tüketim biçimlerini etkileyerek farklı tarihsel zamanlarda sosyo-kültürel değişime neden olmuştur. Tanrılara sunulan kutsal besin bira, sanayi ürününe dönüşmüş ve pazarda yer bulması kültürel etkenlerle birleşerek tüketim ürünü biçiminde alkollü bir içeceğe dönüşmesiyle sonuçlanmıştır. Ekmek ise gündelik önemini görece korusa da arkaik kutsal anlamından sıyrılmış ve üretim mekanlarının değişmesiyle pazarda kendine yer bulmuştur. Yemeye ve içmeye ilişkin toplumsal kültür değişse de ekmek ve bira günümüzde kültürel kalıpların parçası olmaya devam etmektedir.

\section{Kaynakça}

Bloch, M. (2018). Tarih savunusu veya tarihçilik mesleği. (A. Berktay, Çev.). İstanbul: İletişim Yayınları.

Bloch, M. (2019). Feodal toplum. (M. Ali Kılıçbay, Çev.). Ankara: Doğu Batı Yayınları.

Bober, P. P. (2014). Antikçă̆ ve ortaçağda sanat, kültür ve mutfak. (Ü. Tansel, Çev.). İstanbul: Kitap Yayınevi.

Braudel, F. (1958). History and the social sciences: The long term. (Sian France, Çev.). Annales: Economies, Societes, Civilisations, 4, 725 -753. DOI: 10.1177/053901847000900107.

Braudel, F. (2017). Maddi uygarlı: Gündelik hayatın yapıları. (M. Ali Kılıçbay, Çev.). Ankara: İmge Kitabevi.

Braudel, F. (2017a). Maddi uygarlı: Dünyanın zamanı. (M. Ali Kılıçbay, Çev.). Ankara: İmge Kitabevi.

Braudel, F. (2017b). Maddi uygarlık: Mübadele oyunları. (M. Ali Kılıçbay, Çev.). Ankara: İmge Kitabevi.

Burke, P. (1985). Modern Avrupa'nın ilk dönemlerinde toplum ve ekonomiye giriş. A. Boratav (Ed.), Tarih ve tarihçi: Annales okulu izinde içinde, (s. 11-19). İstanbul: Alan Yayıncllı. 
Burke, P. (2008). Kültür tarihi. (M.Tunçay, Çev.). İstanbul: İstanbul Üniversitesi Yayınları.

Burke, P. (2014). Fransız tarih devrimi Annales Okulu. (M. Küçük, Çev.). Ankara: Doğu Batı Yayınları.

Childe, G.V. (2010). Kendini yaratan insan. (F. Ofluoğlu, Çev.). İstanbul: Varlık Yayınları.

Duby, G. (1991). Erkek ortaçă̆. (M. A. Kılıçbay, Çev.). İstanbul: Ayrıntı Yayınları.

Faulkner, N. (2012). Marksist dünya tarihi: Neandertallerden neoliberallere. (T.Öncel, Çev.). İstanbul: Yordam Kitap.

Federici, S. (2012). Caliban ve cadı: Kadınlar, beden ve ilksel birikim. (Ö. Karakaş, Çev.). Otonom Yayıncılık: İstanbul.

Friedell, E. (1999). Antik Yunan'ın kültür tarihi. (N. Aça, Çev.). Ankara: Dost Kitabevi Yayınları.

Genç, Ö. (2016). Çocukların orta çağ Avrupası'ndaki yeri. Vakanüvis - Uluslararası Tarih Araştırmaları Dergisi, 1(1), 241-261. https://doi.org/10.24186/vakanuvis.233672.

Gezgin, İ. (2009). Gılgamış. İstanbul: Alfa Yayınları.

Goody, J. (2013). Yemek, mutfak, sını: Karşılaştırmalı sosyoloji çalışması. (M. G. Güran, Çev.). İstanbul: Pinhan Yayıncllık.

Güvenç, B. (2011). İnsan ve kültür. İstanbul: Boyut Yayıncılık.

Iggers, G. G. (2000). Bilimsel nesnellikten postmodernizme: Yirminci yüzyıl tarihyazımı. (G. Ç. Güven, Çev.) İstanbul: Tarih Vakfı Yurt Yayınları.

Işın, P. M. (2019). Yemeğin kültürel tarihi. İstanbul: Yapı Kredi Yayınları.

Journet, N. (2009). Kültür nedir? N. Journet (Ed.), Evrenselden Özele Kültür içinde (Y. Sezen, Çev.), (s. 15-33). İstanbul: İz Yayıncılık.

Kartari, A. (2014). Kültür, farklılık, iletişim. İstanbul: İletişim Yayınları.

Kempen, R. (2018). Bira. (M. Özen, Çev.). İstanbul: Kolektif Kitap.

Montanari, M. (1995). Avrupa'da yemeğin tarihi. (M. Önen \& B. Hinginar, Çev.). İstanbul: Afa Yayıncılık.

Montanari, M. (2018). Kıtlık ve bolluk. (M. Önen \& B. H. Çoban, Çev.). Ankara: Nika Yayınevi.

Moore, W. J. (2003). Capitalism as world-ecology: Braudel and Marx on environmental history. Organization \& Environment, 16(4), December, 431-458. DOI: 10.1177/1086026603259091.

Phillips, R. (2016). Alkol tarihi. (D. B. Cenkçiler, Çev.). İstanbul: Maya Kitap.

Ponting, C. (2008). Dünyanın yeşil tarihi: Çevre ve büyük uygarlıkların çöküusü. (A. Başçı, Çev.). İstanbul: Sabancı Üniversitesi Yayınları.

Schivelbusch, W. (2000). Keyif verici maddelerin tarihi. (Z. A.Yılmazer, Çev.). Ankara: Dost Kitabevi.

Silvertown, J. (2018). Darwin'le akşam yemeği. (C. E. Topaktaş, Çev.). İstanbul: Kolektif Kitap.

Acar, T. (2008). Maddenin farklı fonksiyonlaşmasını belirlemede kullanılan genelleştirilmiş aşamalı doğrusal modelleme, lojistik regresyon ve olabilirlik oranı tekniklerinin karşılaştırılması (Doktora tezi, Hacettepe Üniversitesi, Ankara). Erişim adresi: http://tez2.yok.gov.tr/ 